\title{
Canada's response to COVID-19 for Indigenous Peoples: a way forward?
}

\author{
Sean A. Hillier ${ }^{1}$ (D) - Elias Chaccour ${ }^{1}$ (D) $\cdot$ Hamza Al-Shammaa $^{1}$ (D) - Jessica Vorstermans ${ }^{1}$
}

Received: 20 September 2020 / Accepted: 25 October 2020 / Published online: 10 November 2020

(C) The Canadian Public Health Association 2020

Dear Editor,

Indigenous Peoples in Canada have borne the brunt of pandemics since the time of European contact, representing a disproportionate burden of infections, including smallpox, influenza, TB, HIV, HepC, and H1N1 (Duncan et al., 2011). Indigenous Peoples still carry the strain of genocidal attitudes and actions, leaving them susceptible to infectious diseases as a result of geographic location and remoteness, underlying health issues, advanced age, lack of healthcare infrastructure, access to clean drinking water and housing, among others (Levesque \& Thériault, 2020a). There has been and continues to be chronic underfunding of Indigenous healthcare needs in Canada (Levesque \& Thériault, 2020a). For generations, Indigenous people's health has not been a priority, even though Indigenous communities are effectively governed as though they are wards of the state. The Canadian government is all too familiar with the poor living conditions and lack of healthcare services that plague Indigenous communities, which place them at greater risk during a pandemic (Carling $\&$ Mankani, 2020). Nevertheless, there were no preparatory or other initial actions taken to bolster Indigenous communities in their fight against COVID-19 (McBride, 2020).

As the COVID-19 pandemic unfolded, the Canadian government waited until Indigenous leaders expressed persistent and extreme concern for their people before providing dedicated funding (Wright, 2020). These pleas catalyzed longawaited actions directed towards Indigenous communities to improve housing, access to safe water, and healthcare services (Vogel, 2020). While the government's reactionary response evolved, the funding specified for Indigenous Peoples, who make up $4.9 \%$ of the population, has equalled just $1 \%$ of the

Sean A. Hillier

shillier@yorku.ca

1 School of Health Policy \& Management, Faculty of Health, York University, 348A Stong College, 4700 Keele St, Toronto, ON M3J 1P3, Canada federal money allocated during the COVID-19 response (Levesque \& Thériault, 2020b). The funding now distributed to Indigenous communities for their directed use means that Indigenous communities are bypassing existing colonial structures that have historically controlled their sovereignty over expenditures. It is our hope that this change, at the moment temporary, in the colonial paternalistic relationship between Canada and Indigenous Peoples, may signal an openness of the federal government to finally recognize the validity of Indigenous nationhood and the communities' sovereign right to manage the pandemic within their territories.

Throughout the pandemic, we have witnessed many Indigenous communities in Canada assert their authority in dealing with the COVID-19 virus, including creating their own public health orders, restricting travel through their territory, adapting their ceremonies, and intensifying public health campaigns. These actions must be recognized as an expression of Indigenous nationhood and a continued assertion of sovereignty. These community-led actions have, in part, led to a less severe impact of COVID-19 on Indigenous communities when compared to the general public (Government of Canada, 2020). The success of Indigenous communities in fighting COVID-19 needs to be clearly articulated as a result, alongside other factors, of Indigenous voices and outcry demanding the provision of federal funds for equitable care during the pandemic (Black, 2020). The assertion of Indigenous sovereignty is essential for efficient healthcare development for Indigenous communities in Canada.

Funding We are grateful for the support of the Social Sciences and Humanities Research Council of Canada, Imagining Age-Friendly "Communities" within Communities: International Promising Practices (https://imagine-aging.ca/). We are indebted to the Principal Investigator on this project, Dr. Tamara Daly, and to the co-investigators, for their encouragement and ever-helpful critique. Sean Hillier is a member of the Global 1 Health Network (http://global1hn.ca/), supported by a grant from the Canadian Institutes of Health Research (CIHR), Funding Reference No. NGR-167542, with additional research funding from CIHR Funding Reference No: 439801. Research findings from these grants do not necessarily reflect the opinions of CIHR. 


\section{Compliance with ethical standards}

Conflict of interest The authors declare that they have no conflict of interest.

\section{References}

Black, M. (2020). COVID-19 in Canada: fears mount that Indigenous communities could be left behind. Global Citizen. https://www. globalcitizen.org/en/content/covid-19-in-canada-indigenouscommunities/

Carling, A., \& Mankani, I. (2020). Systemic inequities increase Covid-19 risk for Indigenous people in Canada. Human Rights Watch. https:// www.hrw.org/news/2020/06/09/systemic-inequities-increasecovid-19-risk-indigenous-people-canada

Duncan, K. C., Reading, C., Borwein, A. M., Murray, M. C., Palmer, A., Michelow, W., Samji, H., Lima, V. D., Montaner, J. S., \& Hogg, R. S. (2011). HIV incidence and prevalence among Aboriginal peoples in Canada. AIDS Behaviour, 15, 214-227. https://doi.org/10.1007/ s10461-010-9792-y.
Government of Canada. (2020). Coronavirus (COVID-19) and Indigenous communities. Indigenous Services Canada. https:// www.sac-isc.gc.ca/eng/1581964230816/1581964277298

Levesque, A., \& Thériault, S. (2020a). Chapter D-6: systemic discrimination in government services and programs and its impact on First Nations peoples during the COVID-19 pandemic. Vulnerable (pp. 381-392). Ottawa: University of Ottawa Press.

Levesque, A., \& Thériault, S. (2020b). Indigenous communities at increased risk during the coronavirus pandemic. The Conversation. https:/theconversation.com/indigenous-communities-at-increasedrisk-during-the-coronavirus-pandemic-142027

McBride, B. (2020). Indigenous communities not ready for possible COVID outbreaks. NNSL Media. https://nnsl.com/yellowknifer/ indigenous-communities-not-ready-for-possible-covid-outbreaks/

Vogel, L. (2020). COVID-19: a timeline of Canada's first-wave response. Can Med Assoc J. https://cmajnews.com/2020/06/12/coronavirus$1095847 /$

Wright, T. (2020). Canada's Indigenous leaders say more help is needed as COVID-19 outbreaks rise. Global News. https://globalnews.ca/ news/6923971/coronavirus-canada-indigenous-concerns/

Publisher's note Springer Nature remains neutral with regard to jurisdictional claims in published maps and institutional affiliations. 